\title{
NILAI-NILAI BUDAYA YANG TERDAPAT PADA BENDA-BENDA PENINGGALAN PURBAKALA DAN UPAYA PELESTARIANNYA
}

\author{
${ }^{1}$ LR. Retno Susanti \\ ${ }^{1}$ Universitas Sriwijaya \\ retnosusanti@gmail.com
}

\begin{abstract}
Abstrak
Peninggalan purbakala bangsa Indonesia telah diketahui berkembang sejak masa Prasejarah sampai masa kini, dan merupakan warisan budaya dari nenek moyang yang sangat tinggi nilainya, baik sebagai sumber sejarah maupun sebagai sumber inspirasi bagi kehidupan bangsa masa kini dan yang akan datang. Oleh karena itu pemahaman mengenai nilai-nilai budaya peninggalan purbakala sangat penting untuk dapat mengetahui sejarah kehidupan nenek moyang kita.
\end{abstract}

Kata Kunci: Nilai-Nilai Budaya, Benda-Benda Peninggalan Purbakala.

\section{PENDAHULUAN}

Peninggalan purbakala sebagai warisan leluhur adalah merupakan bukti sejarah yang dapat berfungsi sebagai suatu media untuk memupuk kepribadian bangsa baik untuk masa kini maupun untuk masa yang akan datang. Oleh karena itu, upaya pelestarian benda-benda peninggalan sejarah sangat penting guna melindunginya dari kehancuran akibat ulah manusia maupun proses alamiah. Warisan budaya tersebut akan senantiasa menjadi sumber inspirasi daya cipta kehidupan bangsa, sekaligus menjadi landasan kesadaran nasional dalam pembangunan (Widodo, 1992:32).

Di tanah air kita banyak sekali ditemukan benda-benda purbakala peninggalan nenek moyang. Namun benda-benda tersebut hanyalah akan menjadi seonggok benda tak bermakna bilamana tak ada upaya untuk penafsirannya atau memahami makna yang tersirat didalamnya. Hal ini dikarenakan benda-benda purbakala merupakan wujud atau hasil aktivitas manusia masa lalu. Oleh karena itu pemahaman mengenai nilai-nilai budaya peninggalan purbakala sangat penting untuk dapat mengetahui sejarah kehidupan nenek moyang kita. Memahami sejarah kehidupan nenek moyang akan meningkatkan apresiasi kita akan eksistensi mereka di antara bangsa-bangsa lain pada masa itu. Eksistensi mereka di tengah-tengah bangsa lain sangat ditentukan oleh kualitas kemanusiaan yang mereka miliki. Kualitas kemanusiaan mereka ditentukan oleh nilai budaya yang dimilikinya (Montana, 1992:41).

Warisan budaya nenek moyang merupakan peninggalan purbakala yang sangat tinggi nilainya, baik sebagai sumber sejarah maupun sebagai sumber inspirasi bagi 
kehidupan bangsa di masa kini dan yang akan datang. Oleh karena itu diperlukan upayaupaya untuk memahami nilai-nilai budayanya dan melestarikan benda-benda tersebut. Namun kurangnya rasa memiliki warisan budaya bangsa tersebut sering terjadi tindakan-tindakan tidak bertanggungjawab.

Adapun pengertian budaya (sering juga disebut kebudayaan) adalah keseluruhan sistem gagasan, tindakan, dan hasil karya manusia dalam rangka kehidupan masyarakat yang dijadikan milik diri manusia dengan belajar (Koentjaraningrat, 1984: 9; dan 1986: 180). J.J. Honigmann dalam The World of Man (1959) membedakan adanya tiga gejala kebudayaan, yaitu ideas, activities, dan artifacts. Sejalan dengan hal tersebut Koentjaraningrat mengemukakan bahwa kebudayaan dapat digolongkan dalam tiga wujud. Pertama, wujud kebudayaan sebagai suatu kompleks ide-ide, gagasan, nilainilai, norma-norma, dan peraturan. Wujud pertama merupakan wujud ideal dari kebudayaan yang bersifat abstrak (tidak dapat diraba, dipegang, atau difoto), berada di alam pikiran warga masyarakat di mana kebudayaan yang bersangkutan hidup. Kebudayaan ideal ini disebut pula tata kelakukan yang berfungsi mengatur, mengendalikan, dan memberi arah kepada tindakan, kelakuan, dan perbuatan manusia dalam masyarakat.

Para ahli antropologi dan sosiologi menyebut wujud ideal dari kebudayaan ini dengan cultural system (sistem budaya) yang dalam bahasa Indonesia dikenal dengan istilah adat atau adat istiadat (dalam bentuk jamak). Kedua, wujud kebudayaan sebagai suatu kompleks aktivitas serta tindakan berpola dari manusia dalam masyarakat. Wujud kebudayaan tersebut dinamakan sistem sosial (social system).

Wujud kebudayaan ini dapat diobservasi, difoto, dan didokumentasi karena dalam sistem sosial ini terdapat aktivitas-aktivitas manusia yang berinteraksi satu dengan yang lain. Sistem sosial merupakan perwujudan kebudayaan yang bersifat konkret dalam bentuk perilaku dan bahasa. Ketiga, wujud kebudayaan sebagai bendabenda hasil karya manusia; bersifat paling konkret dan berupa benda-benda atau hal-hal yang dapat dilihat, diraba, dan difoto. Wujud kebudayaan yang ketiga ini disebut kebudayaan fisik (material culture).

Ketiga wujud kebudayaan dalam realitas kehidupan masyarakat tentu tidak dapat dipisahkan antara satu dengan yang lain. Kebudayaan ideal mengatur dan memberi arah kepada tindakan dan karya manusia. Ide-ide dan tindakan menghasilkan benda-benda yang merupakan kebudayaan fisik. Sebaliknya kebudayaan fisik membentuk lingkungan 
hidup tertentu yang dapat mempengaruhi tindakan dan cara berpikir masyarakat (Koentjaraningrat, 1984: 5-6; dan 1986: 186-188).

Sementara itu, budaya lokal merupakan istilah yang biasanya digunakan untuk membedakan suatu budaya dari budaya nasional (Indonesia) dan budaya global. Budaya lokal adalah budaya yang dimiliki oleh masyarakat yang menempati lokalitas tertentu yang berbeda dari budaya yang dimiliki oleh masyarakat yang berada di tempat yang lain. Di Indonesia istilah budaya lokal juga sering disepadankan dengan budaya etnik/ subetnik atau budaya daerah.

Sumber daya budaya mencakup tiga wujud kebudayaan tersebut. Dengan kata lain sumberdaya budaya tidak hanya yang bersifat kebendaan saja, dan juga tidak hanya yang berasal dari masa lampau. Dalam arti yang luas, sumberdaya budaya meliputi hasil-hasil budaya baik yang kebendaan dan dapat disentuh (tangible) (benda cagar budaya) maupun yang nonbenda (intangible) seperti konsep-konsep dan ekspresiekspresi budaya melalui suara dan atau gerak yang berlalu dalam waktu (Sedyawati, 2006a: 94).

Hasil peninggalan budaya masa lampau ditinggalkan dalam bentuk salah satunya adalah pewarisan nilai-nilai budaya. Adapun pewarisan nilai-nilai budaya ini adalah diwujudkan melalui pemahaman akan makna nilai-nilai tersebut, dan pelestarian terhadap benda-benda peninggalan purbakala hasil karya manusia masa lalu sebagai warisan leluhur yang sampai pada kita saat ini, antara lain berupa: alat-alat dari batu, tembikar, arca, prasasti, monumen (candi), dan masih banyak lagi. Benda-benda tersebut ada yang masih utuh, tetapi sebagian besar sudah rusak atau hancur, ada yang tersimpan di museum, dan ada juga yang masih berada di tempat asalnya, baik dipermukaan maupun terpendam di dalam tanah.

Oleh karena itulah maka dalam tulisan ini akan dibahas dua masalah yaitu pertama, nilai-nilai budaya apa saja yang terdapat di dalam benda peninggalan purbakala, dan yang kedua adalah bagaimana upaya melestarikan benda peninggalan purbakala tersebut.

\section{METODE PENELITIAN}

Penelitian ini menggunakan metode penelitian sejarah. Penelitian sejarah merupakan penelitian tentang suatu peristiwa di masa lampau. Penelitian ini menggunakan prosedur kerja yaitu; Pertama, heuristik, Heuristik berasal dari kata Yunani heurishein yang artinya memperoleh (Abdurrahman 2007: 64). Menurut 
Amminudin (1991: 11) menyatakan heuristik adalah proses mencari dan menemukan sumber yang diperlukan. Dari kedua pendapat diatas heuristik adalah tekhnik yang bisa membantu peneliti untuk memperoleh sumber yang dibutuhkan dalam penelitian. Data penelitian ini diperoleh melalui telah pustaka dengan mengumpulkan buku-buku yang berkaitan dengan topik penelitian ini. Data yang diperoleh melalui telaah pustaka itu tidak hanya dapat disimpan dalam ingatan semata, tetapi dengan membuat catatancatatan dari sumber-sumber yang ditelaah tersebut. Sesuai dengan jenis penelitian ini yakni analisis dokumen/analisis isi yang lebih bersifat kepustakaan murni, maka sumber data yang digunakan adalah sumber primer dan sumber sekunder. Setelah sumber sejarah dalam berbagai kategorinya itu terkumpul tahap berikutnya adalah verifikasi atau kritik untuk memperoleh keabsahan sumber. Dalam hal ini dilakukan uji keabsahan sumber (auntentisitas) yang dilakukan melalui kritik ekstern dan keabsahan tentang kesahihan sumber (kredibelitas) yang diselusuri melalui kritik intern (Abdurahman, $2007: 68)$.

Tahap kedua adalah interprestasi. Setelah peneliti mengumpulkan sumber, kemudian memverifikasi atau melakukan keritik sumber, maka langkah selanjutnya yakni melakukan interpretasi (analisis) terhadap sumber yang telah dianalisis tersebut. Interprestasi sejarah sering disebut juga dengan analisis sejarah. Dalam hal ini, ada dua metode yang digunakan, yaitu analisis dan sintesis.. Keduanya dipandang sebagai metode utama didalam interprestasi (Kuntowijoyo, 1995 : 100). Jadi interprestasi adalah hasil pemikiran berupa panafsiran, pengertian, pemahaman.

Terakhir yaitu, historiografi. Historiografi merupakan cara penulisan, pemaparan atau pelaporan hasil penelitian sejarah yang telah dilakukan. Seperti laporan penelitian ilmiah, penulisan hasil penelitian sejarah hendaknya dapat memberikan gambaran yang jelas mengenai proses penelitian dari awal sampai dengan akhir. Berdasarkan penulisan sejarah itu pula, akan dapat dinilai apakah penelitian itu berlangsung sesuai dengan prosedur yang dipergunakan atau tidak, apakah sumber atau data yang mendukung penarikan kesimpulan memiliki validitas dan realibilitas yang memadai ataukah tidak, jadi dengan penulisan itu akan dapat ditentukan mutu penelitian sejarah itu sendiri. 


\section{HASIL DAN PEMBAHASAN}

\section{Nilai-nilai budaya dalam Benda-benda Peninggalan Purbakala}

Dari berbagai benda peninggalan pubakala dapat diketahui bahwa kebudayaan pada masa prasejarah dapat dikatakan sebagai dasar kebudayaan bangsa Indonesia. Dalam perkembangannya kebudayaan ini diperkaya dengan kebudayaan Hindu-Buddha dan kemudian oleh kebudayaan Islam. Kemampuan dalam penyeleksian dan pengadaptasian kebudayaan dari luar sering disebut dengan loval genius atau kemampuan nenek moyang untuk menyeleksi dan mengadaptasikan budaya yang datang dan mempengaruhi budaya asli ini bisa pula kita sebut dengan nilai budaya terbuka selektif (Widodo, 1992:34). Salah satu contoh adalah Candi Borobudur yang merupakan candi Buddha tersebar di Indonesia, ternyata bentuknya masih berakar pada bentuk bangunan prasejarah, yaitu punden atau teras berundak. Adapun contoh lainnya adalah bentuk halaman candi Panataran maupun candi Sukuh yang mengacu pada konsep teras berundak (Soekmono, 1986:).

Kemampuan penyeleksian dan pangadaptasian kebudayaan asing oleh nenek moyang bangsa Indonesia terbukti lagi pada masa kedatangan kebudayaan Islam.Walaupun kebudayaan Islam telah masuk dan diterima, namun kebudayaan lama yaitu kebudayaan pra Islam masih dipertahankan. Seperti contohnya yang terdapat pada ornamen ukiran pada masjid Mantingan. Pada masjid tersebut terdapat ukiran dengan motif hewan yang digambarkan dengan distilir (disamarkan). Ornamen dengan motif hewan adalah budaya dari masa Hindu-Buddha. Sementara itu dalam agama Islam terdapat larangan membuat lukisan makhluk hidup (hewan dan manusia). Oleh karena seniman-seniman pada waktu itu tak mau kehilangan kreativitas yang sesusi dengan jiwanya, maka muncullah lukisan-lukisan dengan gaya stilir sebagai jalan tengahnya (Kusen, 1985:15-29). Lukisan yang berupa ukiran dengan gaya stiliran tersebut menunjukkan bahwa nenek moyang bangsa Indonesia pada waktu itu dalam menerima budaya baru (budaya Islam) masih terjiwai oleh kepribadiannnya.

Nilai budaya yang tak kalah pentingnya yaitu nilai budaya musyawarah mufakat. Hal ini dapat diketahui berdasarkan data purbakala bahwa sejak manusia hidup menetap, yaitu pada masa bercocok tanam, telah ada bangunan yang agak luas berbentuk seperti wantilan sekarang yang salah satu kegunaanya adalah untuk tempat bermusyawarah. Sampai sekarangpun di setiap desa masih ditemukan balai desa yang salah satu fungsinya adalah sebagai tempat warga desa bermusyawarah (Rata, 1993:15). 
Nilai budaya selanjutnya yang dimiliki nenek moyang bangsa Indonesia adalah nilai budaya mengutamakan kerja. Nilai budaya ini tampak jika melihat hasil budayanya, seperti manik-manik misalnya. Dalam keterbatasan teknologi masa itu, telah mampu diciptakan manik-manik yang indah dengan ukuran yang sangat kecil (kurang dari 0,5 Cm) dengan lubang di tengah. Dapat dibayangkan kesulitan membuatnya, akan tetapi itu dikerjakan demi mutu benda karyanya (Widodo, 1992:36). Nilai budaya yang juga sangat penting yaitu nilai budaya toleransi beragama. Nilai budaya ini tampak jika kita melihat pendirian candi-candi dari agama Hindu, seperti candi Dieng, Gedong Songo, dan kompleks candi prambanan berdekatan dengan candi-candi Budha seperti candi Pawon, Mendut, dan Borobudur.

Nilai Budaya yang lainnya adalah nilai budaya gotong royong. Sifat menggalang kesatuan itu tersirat dari benda-benda purbakala sejak masa prasejarah. Pada masa ini telah dikenal adanya batu-batu besar (megalitik) yang dipakai sebagai obyek pemujaan atau wadah kubur. Bangunan-bangunan tersebut seringkali dbuat dari batu-batu yang beratnya berton-ton. Oleh karena itu dapat dibayangkan cara kerja mereka. Mengingat teknologi yang sederhana maka koordinasi kerja menjadi bagian yang penting. Hal ini juga terlihat pada masyarakat megalitik yang masih ada hingga sekarang seperti di Sumba. Pendirian bangunan megalitik dan segala upacaranya dilakukan bersama-sama oleh masyarakat. Nilai budaya ini juga menjiwai pendirian bangunan-bangunan masa Hindu-Buddha. Kebesaran bangunan candi Borobudur atau Prambanan muncul sebagai hasil ungkapan pengabdian bagi masyarakat dan negara mereka. Kesadaran yang tinggi untuk saling mengisi dan bersatu dalam mencapai tujuan bersama mendorong mereka untuk mampu menciptakan karya-karya agung (Aristanudirdjo, 1984:23).

\section{Upaya Pelestarian Benda Peninggalan Purbakala}

Pengertian pelestarian dalam pembahasan ini dimaksudkan sebagai usaha untuk tetap mengabadikan nilai-nilai budaya yang terdapat dalam benda peninggalan purbakala agar memantapkan kepribadian kita guna menghadapi budaya luar pada saat ini dan masa yang akan datang. Benda-benda peninggalan purbakala adalah salah satu warisan budaya bangsa yang masih bertahan hingga kini, walaupun sebagian besar keadaannya sudah tidak utuh lagi. Keadaan ituakan menjadi semakin parah oleh karena ulah manusia yang tidak bertanggungjawab serta tidak mempunyai rasa memiliki warisan budaya tersebut. Pencurian benda-benda kuna untuk kepentingan pribadipribadi sering terjadi, bentuk-bentuk perusakan berupa corat-coret di obyek-obyek purbakala masih juga sering dilakukan. Di samping itu juga adanya pemugaran liar, 
dalam arti tidak sesuai dengan prinsip-prinsip pemugaran bangunan kuna. Semua itu akan mengakibatkan rusak/hilangnya data-data sejarah kehidupan bangsa kita di masa lampau, sehingga akan mengaburkan upaya-upaya pelacakan nilai-nilai budaya yang merupakan kepribadian bangsa.

Guna mengantisipasi keadaan yang makin parah dari benda-benda peninggalan purbakala tersebut upaya-upayapun telah dilakukan yaitu dengan pelestarian warisan budaya. Pelestarian warisan budaya ini meliputi inventarisasi, pemeliharaan, pemugaran, pengamanan, serta pendokumentasian. Kegiatan tersebut diharapkan dapat mampu menyelamatkan benda-benda warisan budaya dari keadaan yang lebih parah. Namun kerja yang mulia ini akan sia-sia apabila tak diimbangi oleh kesadaran masyarakat akan makna serta rasa memiliki warisan budaya tersebut. Oleh karena itu di sini perlu ditekankan upaya menggugah kesadaran masyarakat untuk lebih memahami serta mempunyai rasa memiliki warisan budaya bangsanya (Widodo, 1992:38).

Untuk menggugah kesadaran masyarakat akan arti pentingnya peninggalanpeninggalan purbakala dapat ditempuh melalui jalur pendidikan maupun media massa.

\section{Jalur Pendidikan}

Penyadaran masyarakat akan nilai-nilai budaya benda peninggalan purbakala dapat dilakukan melalui jalur pendidikan formal maupun non formal. Melalui pendidikan formal dapat dilakukan melalui sekolah-sekolah. Sejak sekolah dasar perlu diberikan ajaran tentang rasa kecintaan terhadap benda-benda peninggalan purbakala. Hal ini dapat dilakukan dengan cara mengunjungi obyek-obyek peninggalan purbakala serta pengajaran sejarah kebudayaan. Melalui pendidikan non formal dapat dilakukan melalui penyuluhan-penyuluhan terhadap masyarakat oleh aparat pemerintah setempat ataupun oleh instansi yang berkompeten. Materi penyuluhan seyogyanya disusun sedemikian rupa sehingga mudah dimengerti oleh masyarakat.

\section{Jalur Media Massa}

Penyadaran makna benda peninggalan purbakala melalui media massa seperti surat kabar, radio, ataupun televisi dapat disajikan atau ditayangkan hal-hal yang berhubungan dengan purbakala serta arti pentingnya nilai-nilai budaya dari warisan nenek moyang. Selain itu diupayakan pula penerbitan-penerbitan buku-buku ataupun brosur-brosur yang berisi pengetahuan tentang kepurbakalaan, serta pameran kepurbakalaan oleh instansi yang berkompeten. Upaya ini hanyalah sebagian kecil dari upaya penyadaran masyarakat akan arti pentingnya warisan budaya bangsa. 


\section{KESIMPULAN}

Berdasarkan pemahaman akan nilai-nilai budaya yang terdapat di dalam peninggalan purbakala ternyata dapat disimpulkan bahwa nilai-nilai budaya yang luhur tersebut terdiri, yaitu; (1) nilai budaya terbuka selektif; (2) nilai budaya musyawarah mufakat; (3) nilai budaya mengutamaka kesempurnaan kerja; (4) nilai budaya toleransi beragama; dan (5) nilai budaya gotong royong. Kelima nilai luhur tersebut merupakan warisan nenek moyang yang dapat ditemukan melalui pemahaman akan makna benda-benda hasil karya mereka. Dengan demikian merupakan suatu keharusan bagi generasi selanjutnya untuk melestarikannya melalui jalur pendidikan dan media massa.

\section{DAFTAR PUSTAKA}

Aminuddin Kasdi. 1993. Pengantar Ilmu Sejarah. Surabaya: Universitas Press IKIP.

Aristanudirdjo, 1984. "Relevansi arkeologi di Masa Kini", Dalam Majalah Artefak. Yogyakarta: Fakultas Sastra UGM.

Dudung Abdurrahman. 2007. Metodologi Penelitian Sejarah. Jakarta: Ar-Ruzzmedia.

Koentjaraningrat. 1974. Kebudayaan Mentaliteit dan Pembangunan. Jakarta: PT Gramedia.

Kuntowijoyo. 1995. Metodologi Sejarah. Yogyakarta: PT. Tiara Wacana Yogya.

Kusen. 1976. Kreativitas dan Kemandirian Seniman Jawa dalam Mengolah Pengaruh Budaya Asing dalam Peninggalan Arkeologi dalam Kebudayaan Islam (Proyek Javanologi). Tidak diterbitkan.

Montana, Suwedi. 1992. Konsep Identitas Bangsa yang Tampak pada Tinggalan Arkeologi. Jakarta: Puslit Arkenas.

Rata, Ida Bagus. 1993. "Manfaat Arkeologi bagi Pembangunan”, dalam Majalah Widya Pustaka. Denpasar: Fakultas Sastra Universitas Udayana.

Soekmono, R. 1986. Makna Pemugaran Candi Borobudur dalam Makna Peninggalan Arkeologi dalam Kebudayaan Jawa (Proyek Javanologi). Tidak diterbitkan.

Tjandrasasmita, Uka. 1976. Sepintas Mengenai Peninggalan Islam di Pesisir Utara Jawa. Jakarta: Puslit Arkenas.

Widodo, Sambung. 1992. Makna Tinggalan Arkeologi Sebagai Warisan Leluhur. Jakarta: Puslit Arkenas. 